\title{
Stimulatory effect of insulin on ruminal epithelium cell mitosis in adult sheep
}

\author{
BY T. SAKATA,* K. HIKOSAKA, $†$ YOKO SHIOMURA \\ AND H. TAMATE \\ Department of Animal Science, Faculty of Agriculture, \\ Tohoku University, 980 Sendai, Japan
}

(Received I3 August I979-Accepted 4 June I980)

I. The rumen adapts to increased food intake by the hyperplasia of epithelial cells.

2. Volatile fatty acids (VFA) stimulate cell mitosis of sheep ruminal epithelium in vivo.

3. Since VFA generally inhibit cell proliferation in vitro insulin was proposed in this study as the possible mediator of the mitotic stimulation in vivo.

4. Infusions ( $6 \mathrm{~h})$ of insulin ( $0.125 \mathrm{U} / \mathrm{kg}$ per h) plus glucose $(300 \mathrm{mg} / \mathrm{kg} \mathrm{per} \mathrm{h)}(n$ 5), and glucose alone $(300 \mathrm{mg} / \mathrm{kg}$ per h) $(n \mathrm{n})$ resulted in higher mitotic index of biopsied rumen epithelium (MI) during 3 or 6 to $24 \mathrm{~h}$ after the start of infusion, and higher plasma immunoreactive insulin (IRI) and higher plasma glucose (PG) during the infusion.

5. Insulin plus glucose infusion showed higher MI, higher IRI, and lower PG than glucose infusion.

6. Sheep infused with saline for $6 \mathrm{~h}\left(n_{1}\right)$ showed no marked changes in MI, IRI, and PG.

7. Increased IRI by insulin plus glucose or glucose alone infusion was considered to stimulate cell proliferation in rumen epithelium.

8. Other possible mediations were discussed.

The rumen adapts to a more than 3 -fold increase in the food intake in lactating sheep (Fell \& Weekes, 1975). This adaptation is done by the hyperplasia of the epithelial cells morphologically (Fell \& Weekes, 1975) and functionally (Weekes, 1972). On the other hand, domestic ruminants sometimes fail to adapt to a high-cereal diet suffering from rumenitis or rumen parakeratosis or both (Jensen \& Mackey, 1965; Fell et al. 1968; Tamate et al. 1973). These diseases are speculated to be caused by abnormally accelerated epithelial cell proliferation in the rumen (Tamate \& Kikuchi, 1978). Thus the ruminant sometimes fails to adapt to high nutritional plane, although it has the potential to adapt.

Since the epithelial cell mass is determined by the cell production rate and the rate of cell death and the latter is primarily determined by the former (Bullough, 1975), the study of the regulatory mechanism of cell proliferation in this epithelium is important for the ruminant nutrition.

The higher volatile fatty acids' (VFA) production rate was considered as the promoter of the rumen epithelial cell proliferation (Ørskov, 1976). Actually VFA (18 mmol/ $\mathrm{kg} \mathrm{per} \mathrm{d)}$ stimulated rumen epithelial cell proliferation in adult sheep (Sakata \& Tamate, 1978b, 1979). Butyric acid had by far the greatest stimulatory effect (Sakata \& Tamate, I979), with histological alteration of the epithelium and the underlying tissue (Sakata \& Tamate, $1978 c$ ).

On the other hand, in vitro studies show that butyric acid (0.5-100 $\mathrm{mm}$ in the medium) generally inhibits mammalian cell proliferation (Ginsburg et al. 1973; Wright, 1973), usually with alterations in cell shape (Ginsburg et al. 1973; Wright, 1973; Szemerédy \&

\footnotetext{
- Present address: Physiologisches Institut, Tierărztliche Hochschule Hannover, D-3000 Hannover I, West Germany.

+ Present address: Department of Biology, Tohoku Dental University, Koriyama, Fukushima, Japan.
} 
Raul, 1976; Macher et al. 1978; Mori et al. 1979) different from those in cells exposed to butyrate in vivo (Sakata \& Tamate, $1978 c$ ).

This contradiction between studies in vivo and in vitro suggests the existence of hormonal mediation, not present in the in vitro preparations. So far there are two hormones, insulin and glucagon, known to be released by butyric and propionic acid (Manns \& Boda, I967; Jordan \& Phillips, 1978) (the situation with acetic acid is not clear (Brockman, 1978)), although the significance of this action remains still questionable (Stern et al. 1970). Insulin is one of the most essential factors (the four factors $(4 \mathrm{~F})$ : insulin, transferrin, putrescine dihydrochloride, and progesterone) for mammalian cell proliferation in vitro (Bottenstein et al. 1979), and thus it was the most likely mediator in VFA-stimulated epithelial cell proliferation. This is supported by the observation that cell proliferation of oral epithelium is depressed in alloxan-treated diabetic rats (Hamilton \& Blackwood, 1977). Apart from this there is no available information on the in vivo effect of insulin on epithelial cell mitosis of the mammalian gastrointestinal tract, though the hormone is very important for the intermediary metabolism for the mammals including the ruminant (Brockman, 1978).

In the study presented here the stimulatory effect of insulin on epithelial cell mitosis in the rumen of adult sheep was shown using the mitotic index in biopsied samples before, during, and after the intravenous infusion of insulin.

\section{MATERIALS AND METHODS}

Two adult castrated male sheep $(36-40 \mathrm{~kg}$ ) with permanent rumen fistulas were kept in individual metabolic cages and were given $700 \mathrm{~g}$ orchard hay and $300 \mathrm{~g}$ concentrates once daily at noon. They were allowed free access to water and a mineral mixture. Feed, water and mineral mixture were withdrawn $\mathrm{I} h$ before the experiments. Polyethylene catheters were placed in both jugular veins at least $3 \mathrm{~d}$ before the experiments.

In five experiments insulin was infused $(0.125 \mathrm{U} / \mathrm{kg}$ per $\mathrm{h})$, together with glucose ( $300 \mathrm{mg} / \mathrm{kg}$ per $\mathrm{h}$ ) to prevent hypoglycaemia. In two control experiments glucose $(300 \mathrm{mg} /$ $\mathrm{kg}$ per $\mathrm{h}$ ) was infused. In one control experiment only physiological saline (0.154 M-sodium chloride solution) was given to check the possible influence of the infusion and sampling procedures. All these solutions were infused into the right jugular vein for $6 \mathrm{~h}$, starting at 12.00 hours, at the rate of $0.5 \mathrm{ml} / \mathrm{min}$ with a peristaltic pump (Mitsumi Seiki Co. Ltd).

Blood samples were collected with heparinized syringes from the left jugular vein at $-1,0,1,2,3,4,5,6,9,12,24$ and $48 \mathrm{~h}$ after the start of the infusion. In the following description all times refer to the period after the start of infusion. Samples were cooled with ice water and were centrifuged at $0^{\circ}$ to obtain plasma. The plasma was frozen and kept at $-20^{\circ}$ until analysis. Plasma glucose (PG) and plasma immunoreactive insulin (IRI) were determined by the glucose oxidase method (Huggett $\&$ Nixon, 1957) and by a radioimmunoassay technique (Herbert et al. 1965), respectively.

Three to five ruminal papillas were biopsied from the region of the atrium ruminis blindly with a pair of Chevalier-Jackson type forceps through the rumen fistula as described before (Sakata \& Tamate, 1978a) at $0,3,6,12,24$, and $48 \mathrm{~h}$. The correctness of the sampling site was already confirmed by the post-mortem examinations of the sheep used in previous experiments (Sakata et al. 1980). Cross sections (approximately I $\mathrm{mm}$ thick) were taken from the middle of the papilla and cut into two pieces sagittally at the middle. These blocks were fixed and embedded as already described (Sakata \& Tamate, I978a). Five blocks were randomly chosen for each sample and every cross section ( $1 \mu \mathrm{m}$ thick) was cut from them. The sections were stained with haematoxylin and eosin. The number of basal cell nuclei of the epithelium and the number of mitotic figures in them were counted and totalled for these five sections. From 1599 to 3514 nuclei were thus counted in each sampling. The 
Table I. Plasma immunoreactive insulin level in fasted adult sheep infused with insulin (0.125 $U / \mathrm{kg}$ per h) plus glucose (300 $\mathrm{mg} / \mathrm{kg} \mathrm{per} \mathrm{h),} \mathrm{glucose} \mathrm{(300} \mathrm{mg} / \mathrm{kg}$ per h) or physiological saline $(30 \mathrm{ml} / \mathrm{h})$ intravenously for $6 \mathrm{~h}$ (0 to $6 \mathrm{~h}$ ) from $\mathrm{I} 2.00$ hours

(Mean values with the standard error of the mean)

Plasma immunoreactive insulin $(\mu \mathrm{U} / \mathrm{ml})$

\begin{tabular}{|c|c|c|c|c|c|c|c|c|c|c|c|c|c|}
\hline $\begin{array}{c}\text { Period of infusion } \\
\text { Infusion }\end{array}$ & n (h) ... & $-I$ & 0 & I & 2 & 3 & 4 & 5 & 6 & 9 & 12 & 24 & 48 \\
\hline $\begin{array}{l}\text { Insulin + glucose } \\
\quad(n \text { 5) }\end{array}$ & $\begin{array}{l}\text { Mean } \\
\text { SEM }\end{array}$ & $\begin{array}{r}20 \cdot 0 \\
3 \cdot 0\end{array}$ & $\begin{array}{r}20 \cdot 0 \\
4 \cdot 7\end{array}$ & $\begin{array}{l}191 \cdot 8 \\
1847\end{array}$ & $\begin{array}{l}208 \cdot 5 \\
168.4\end{array}$ & $\begin{array}{l}159.5 \\
128.3\end{array}$ & $\begin{array}{l}145 \cdot 8 \\
110 \cdot 7\end{array}$ & $\begin{array}{l}147 \cdot 8 \\
105 \cdot 4\end{array}$ & $\begin{array}{r}147 \cdot I \\
96 \cdot 8\end{array}$ & $\begin{array}{r}24 \cdot 0 \\
5 \cdot 8\end{array}$ & $\begin{array}{r}23 \cdot 1 \\
6 \cdot 7\end{array}$ & $\begin{array}{r}18 \cdot 7 \\
4 \cdot 3\end{array}$ & $\begin{array}{r}14 \cdot 4 \\
2 \cdot 0\end{array}$ \\
\hline $\begin{array}{l}\text { Glucose } \\
\qquad\left(\begin{array}{ll}n & 2\end{array}\right)\end{array}$ & $\begin{array}{l}\text { Mean } \\
\text { SEM }\end{array}$ & $\begin{array}{r}24 \cdot I \\
9 \cdot 8\end{array}$ & $\begin{array}{r}17 \cdot 9 \\
1 \cdot 8\end{array}$ & $\begin{array}{l}58 \cdot 5 \\
30 \cdot 0\end{array}$ & $\begin{array}{l}57 \cdot 0 \\
35 \cdot 9\end{array}$ & $\begin{array}{l}63 \cdot 3 \\
36 \cdot 4\end{array}$ & $\begin{array}{l}59 \cdot 6 \\
33 \cdot 6\end{array}$ & $\begin{array}{l}56 \cdot 2 \\
34 \cdot 2\end{array}$ & $\begin{array}{l}75 \cdot 6 \\
55 \cdot 3\end{array}$ & $\begin{array}{r}18 \cdot 1 \\
5 \cdot 4\end{array}$ & $\begin{array}{r}11 \cdot 9 \\
5 \cdot 1\end{array}$ & $\begin{array}{r}16 \cdot 0 \\
7 \cdot 0\end{array}$ & $\begin{array}{r}11 \cdot 2 \\
4 \cdot 1\end{array}$ \\
\hline $\begin{array}{l}\text { Saline } \\
(n \text { I })\end{array}$ & Mean & $43 \cdot 2$ & $21 \cdot 2$ & $23 \cdot 2$ & $21 \cdot 9$ & $2 I \cdot 4$ & $21 \cdot 2$ & $2 I \cdot I$ & $23 \cdot 2$ & 24.0 & 23.6 & 17.9 & $19 \cdot 6$ \\
\hline
\end{tabular}

counting was limited to the epithelium on the flat side of the papillas, because this side is considered to be the main site of absorption (Schnorr \& Vollmerhaus, 1967, I968). As a measure of mitotic activity, the mitotic index (MI) of the rumen epithelium was calculated ; $\mathrm{MI}(\%)=$ (no. of basal cells showing mitotic figures) $/$ (total basal cell nuclei counted) $\times$ I 00 .

Before statistical treatment all values of IRI, PG and MI were transformed into logarithms to stabilize the variance (Snedecor \& Cochran, 1967). The mean value of each variable at a specific time point was compared with the mean value of the initial value (at - I and o h for IRI and PG, or at $o h$ for MI) by Student's $t$ test. The mean value of each variable was also compared between the groups given insulin plus glucose and those given glucose alone by $t$ test at each time point. Two-way (treatment $\times$ time) analysis of variance for unequal numbers (Snedecor \& Cochran, 1967) was also done for each variable. After this the comparisons were made to find the time points which had significantly higher values. For the test of PG and MI the individual differences between the sheep were ignored. Since the individual difference of IRI was large, the analysis was done in each animal. Therefore, the influence of insulin plus glucose infusion and glucose infusion was tested with the IRI of one sheep ( $n_{3}$ and $n_{1}$ ), and the influence of all the three treatments was tested with the IRI of another animal ( $n_{2}, n_{I}$ and $\left.n_{1}\right)$ separately. The difference was considered to be significant at $P<0.05$.

\section{RESULTS}

Both IRI (Table I) and PG (Table 2) significantly increased during the infusions of insulin plus glucose and of glucose alone compared with their initial levels and with the values of the saline control. The IRI level during the infusion was significantly higher in the sheep given insulin plus glucose than in those given glucose alone. On the other hand the PG level during the infusion was significantly higher in the sheep given glucose alone than those given insulin plus glucose. The increased levels of IRI and PG in these animals returned to the initial level after the end of infusions. The saline control showed no significant changes of IRI or PG during the experiment with over-all mean \pm SEM (standard error of the mean) of $23.5 \pm 6.5 \mu \mathrm{U} / \mathrm{ml}$ for IRI and $3.75 \pm 0.37 \mathrm{mmol} / 1$ for PG.

The MI (Fig. I) in the sheep given insulin plus glucose significantly increased from the initial value after $3 \mathrm{~h}$. The increased level was maintained until $24 \mathrm{~h}$ and then returned to the initial level. In the sheep given glucose alone the MI also significantly increased during 6 to $24 \mathrm{~h}$. The increased MI in both cases was significantly different from the MI of the saline control which showed no marked fluctuations during the experiment with the over-all 
Table 2. Plasma glucose level in fasted adult sheep infused with insulin (0.125 $U / \mathrm{kg}$ per $h$ ) plus glucose ( $300 \mathrm{mg} / \mathrm{kg} \mathrm{per} \mathrm{h})$, glucose $(300 \mathrm{mg} / \mathrm{kg} \mathrm{per} \mathrm{h})$ or physiological saline $(30 \mathrm{ml} / \mathrm{h})$ intravenously for $6 \mathrm{~h}$ (0 to $6 \mathrm{~h}$ ) from $\mathrm{I} 2.00$ hours

(Mean values with the standard error of the mean)

Plasma glucose (mmol/1)

\begin{tabular}{|c|c|c|c|c|c|c|c|c|c|c|c|c|c|}
\hline $\begin{array}{l}\text { Period of infusion } \\
\text { Infusion }\end{array}$ & n (h)... & -1 & 0 & I & 2 & 3 & 4 & 5 & 6 & 9 & 12 & 24 & 48 \\
\hline $\begin{array}{l}\text { Insulin + glucose } \\
\text { (n 5) }\end{array}$ & $\begin{array}{l}\text { Mean } \\
\text { SEM }\end{array}$ & $\begin{array}{l}3 \cdot 60 \\
0 \cdot 17\end{array}$ & $\begin{array}{l}3.53 \\
0.22\end{array}$ & $\begin{array}{l}6.07 \\
0.77\end{array}$ & $\begin{array}{l}6 \cdot 92 \\
I \cdot 27\end{array}$ & $\begin{array}{l}6.90 \\
1.69\end{array}$ & $\begin{array}{l}6.87 \\
1.95\end{array}$ & $\begin{array}{l}6.80 \\
1 \cdot 46\end{array}$ & $\begin{array}{l}6.69 \\
1.62\end{array}$ & $\begin{array}{l}2.62 \\
0.84\end{array}$ & $\begin{array}{l}3.32 \\
0.20\end{array}$ & $\begin{array}{l}3.21 \\
0.44\end{array}$ & $\begin{array}{l}2.44 \\
0.52\end{array}$ \\
\hline $\begin{array}{l}\text { Glucose } \\
\quad\left(\begin{array}{ll}n & 2\end{array}\right)\end{array}$ & $\begin{array}{l}\text { Mean } \\
\text { SEM }\end{array}$ & $\begin{array}{l}3 \cdot 40 \\
0 \cdot 24\end{array}$ & $\begin{array}{l}3.51 \\
0.10\end{array}$ & $\begin{array}{l}7.69 \\
0.55\end{array}$ & $\begin{array}{l}9 \cdot 60 \\
0.74\end{array}$ & $\begin{array}{r}10 \cdot 22 \\
1.60\end{array}$ & $\begin{array}{r}10.42 \\
1.88\end{array}$ & $\begin{array}{r}10 \cdot 79 \\
2 \cdot 72\end{array}$ & $\begin{array}{r}10 \cdot 77 \\
2 \cdot 63\end{array}$ & $\begin{array}{l}2.90 \\
1.08\end{array}$ & $\begin{array}{l}3.40 \\
0.36\end{array}$ & $\begin{array}{l}3.39 \\
0.38\end{array}$ & $\begin{array}{l}2.59 \\
0.36\end{array}$ \\
\hline $\begin{array}{l}\text { Saline } \\
(n \text { I })\end{array}$ & Mean & $4 \cdot 13$ & $3 \cdot 87$ & 4.03 & 4.02 & 4.04 & 3.89 & 3.81 & $3 \cdot 73$ & $3 \cdot 76$ & 3.55 & $3 \cdot 33$ & 2.84 \\
\hline
\end{tabular}

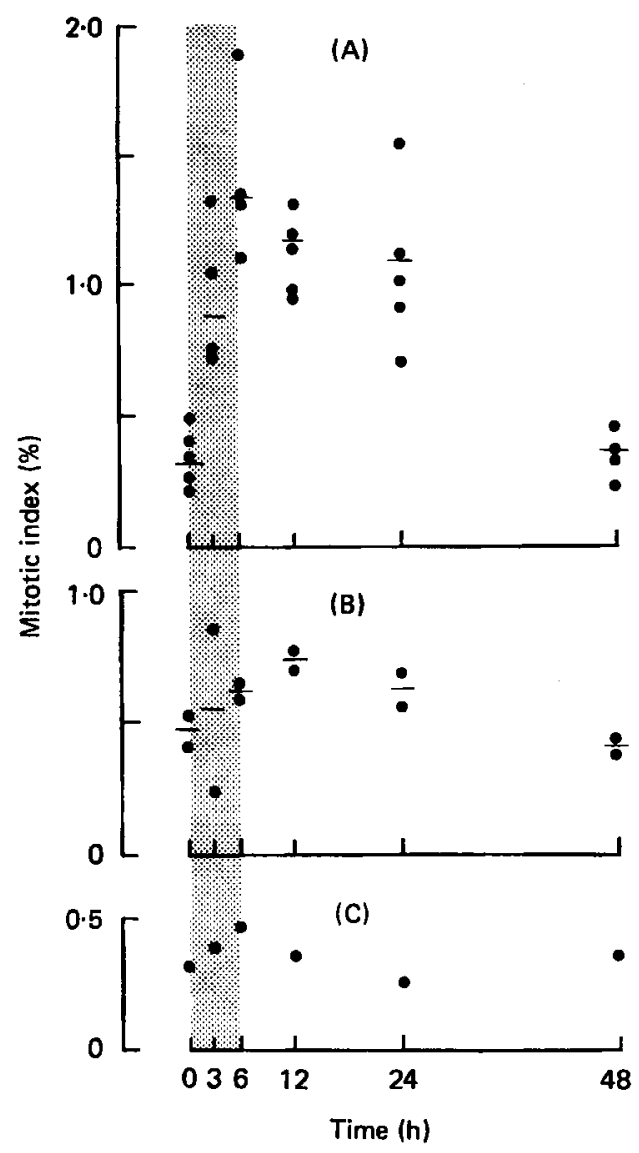

Fig. I. Mitotic index of the epithelial cells in adult sheep rumen before, during and after the infusion of (A) insulin ( $\cdot 125 \mathrm{U} / \mathrm{kg}$ per h) plus glucose ( $300 \mathrm{mg} / \mathrm{kg}$ per h), (B) glucose ( $300 \mathrm{mg} / \mathrm{kg} \mathrm{per} \mathrm{h}$ ), or (C) physiological saline for $6 \mathrm{~h}$ from 12.00 hours at a rate of $0.5 \mathrm{ml} / \mathrm{min}$. (国), The duration of the infusion; horizontal short bars show the mean values. 
mean \pm SEM of $0.60 \pm 0.09 \%$. The increased level of MI in the sheep given insulin plus glucose was significantly higher than that of the sheep given glucose alone.

\section{DISCUSSION}

Mitosis in the rumen epithelium was significantly stimulated both by insulin plus glucose infusion and by glucose infusion in the present study (Fig. I). These infusions also resulted in higher levels of IRI and PG during the infusions (Tables I and 2). We may conclude that the increased IRI caused by these infusions stimulated the mitotic activity in the rumen epithelium, because both MI and IRI were higher in the sheep given insulin plus glucose than in the sheep given glucose alone and PG showed a contrary effect. In other words, the higher the IRI the higher was the MI in three different infusions. Our previous study confirmed histologically the validity of MI as the measure of proliferative activity in the rumen epithelium (Sakata \& Tamate, 1978c). Therefore, we may say that insulin stimulated the epithelial cell proliferation in the adult sheep rumen.

This stimulatory effect of insulin appeared even though the sheep were fasted in this study. Thus the stimulatory effect of insulin dominates the suppressive effect of fasting on rumen epithelial cell proliferation (Tamate et al. 1974). It also suggests that the influence of food intake on the circadian rhythm of rumen epithelial cell mitosis (Sakata \& Tamate, $1978 a$ ) is more or less influenced by fluctuation in plasma insulin level (Bassett, 1974).

The increased level of the MI after insulin plus glucose infusion was comparable to that stimulated by intraruminal administration of sodium $n$-butyrate $(18 \mathrm{mmol} / \mathrm{kg}$ per d) (Sakata \& Tamate, I978b). The increased level of IRI following insulin plus glucose infusion in the present study was about $50 \%$ of the IRI level after intravenous administration of butyrate $(2.5 \mathrm{mmol} / \mathrm{kg}$ ) (Manns \& Boda, 1967). Therefore we considered that our present study well simulated the insulin level after intraruminal administration of butyrate.

Although the physiological significance of VFA was once questioned by Stern et al. (1970), Brockman (1978) concluded in his review: 'It appears that while VFA are not only regulators of insulin and glucagon secretion they certainly play a part.'

Thus it is supposed that the stimulatory effect of intraruminal administration of butyrate and propionate (and possibly acetate) is mediated at least partly through insulin released by the acids.

This is consistent with the recent work of T. Sakata (unpublished results) in rats injected with VFA mixture in the ligated colon pouch, in which VFA stimulated epithelial cell mitosis in various parts of the gastrointestinal tract including the part that had no direct contact with the VFA mixture. There should therefore, have been some mediatory mechanism for this case, too. This mediatory mechanism must have been carried out by a microtubule system, because the stimulatory effect of VFA disappeared on the addition of colchicine and mitotic accumulation by the reagent was observed. This is also consistent with the result of the present study, because insulin secretion is also carried out by a microtubule system (Malaisse-Lagae et al. 1971).

However, we should not neglect the other mediator(s), although little information is available about the mitotic stimulation in the ruminant digestive tract. VFA also stimulate the release of glucagon (Manns \& Boda, 1967; Jordan \& Phillips, 1978) which could be one possible mediator. Gastrin, which stimulates epithelial cell proliferation in various parts of the digestive tract, does not appear to be the mediator for VFA, because the gastrin level is not increased in rats in which colon mucosal growth is stimulated by dietary fibre (so that presumably it is stimulated by microbial fermentation resulting in VFA production) (Ryan et al. 1979). Some gastrointestinal hormones such as pancreozymine (Baile et al. 1969; Trenkle, 1972), secretin (Trenkle, 1972), tetragastrin ( Y. Sasaki, personal communica- 
tion), or cerulein (Y. Sasaki, personal communication) can stimulate insulin release in the ruminant. Therefore, these hormones could stimulate the rumen epithelial cell proliferation indirectly through the increase in plasma insulin level. Neural mediation is another possible mechanism. Sympathetic nerves seem to be more likely for this case than the vagus nerve, because the former generally stimulate cell proliferation and the latter generally depresses it in the digestive tract of non-ruminant animals (Eastwood, 1977).

Whatever the mediator is, the mediatory mechanism for the mitotic stimulation by VFA should have two critical points which determine the sensitivity of the animal against the stimulation of VFA. One is the sensitivity of the mediator against VFA and another is the sensitivity of the epithelial cells against the mediator. The different sensitivities may explain the differing abilities of adaptation to varied nutritional conditions resulting in varied VFA production at different ages (Tamate, I957) and reproductive state (Fell \& Weekes, 1975).

In conclusion, insulin stimulated epithelial cell proliferation in the rumen and the hormone may, at least partly, mediate mitotic stimulation by VFA in vivo.

This study was partly supported by Grant-in-Aid for Scientific Research from the Ministry of Education of Japan (No. 356I95). The authors thank Dr Y. Sasaki for his advice and for his kind permission to use his unpublished results and Professor W. von Engelhardt and Dr I. D. Hume for their critical reading of our manuscript. The authors also thank Ms U. Nolda for her assistance with the illustration.

\section{REFERENCES}

Baile, C., Glick, Z. \& Mayer, J. (1969). J. Dairy Sci. 52, 513.

Bassett, J. M. (1974). Aust. J. biol. Sci. 27, 167.

Bottenstein, J. M., Hayashi, I., Hutchings, S., Masui, H., Mather, J., McClure, D. B., Ohasa, S., Rizzino, A., Sato, G., Serrero, G., Wolfe, R. \& Wu, R. (1979). In Methods in Enzymology, vol. Lvm, p. 94. London and New York: Academic Press.

Brockman, R. P. (1978). Can. vet. J. 19, 55.

Bullough, W. S. (1975). Biol. Rev. 50, 99.

Eastwood, G. L. (1977). Gastroenterol. 72, 962.

Fell, B. F., Kay, M., Whitelaw, F. G. \& Boyne, R. (1968). Res. vet. Sci. 9, 458.

Fell, B. F. \& Weekes, T. E. C. (1975). In Metabolism in the Ruminants, p. IoI [I. W. McDonald and

A. C. I. Warner, editors]. Armidale: University of New England Publishing Unit.

Ginsburg, E., Salomon, D., Sreevalsan, T. \& Freese, E. (1973). Proc. natn. Acad. Sci. 70, 2457.

Hamilton, A. I. \& Blackwood, H. J. J. (1977). J. Anat. 124, 757.

Herbert, V., Law, K., Bottlieb, C. W. \& Bleicher, S. (1965). J. clin. Endocr. Metab. 25, 375.

Huggett, A. G. \& Nixon, D. A. (1957). Biochem. J. 66, I 29.

Jensen, R. \& Mackey, D. R. (1965). In Disease of Feedlot Cattle, p. 282. Philadelphia: Lea and Febiger.

Jordan, H. N. \& Phillips, R. W. (1978). Am. J. Physiol. 234, E I62.

Macher, B. A., Lockey, F., Fung, Y. K. \& Seeley, C. C. (1978). Expl Cell Res, rr7, 95.

Malaisse-Lagae, F., Greider, M. H., Malaisse, W. J. \& Lacy, P. E. (I971). J. Cell Biol. 49, 530.

Manns, J. G. \& Boda, J. M. (1967). Am. J. Physiol. 212, 747.

Mori, Y., Akedo, H., Tanigawa, Y. \& Okada, M. (1979). Expl Cell Res. Ir8, I5.

Orskov, E. R. (1976). Proc. Nutr. Soc. 35, 245.

Ryan, G. P., Dudrick, S. J., Copeland, E. M. \& Johnson, L. R. (1979). Gastroenterol. $77,658$.

Sakata, T., Hikosaka, K., Shiomura, Y. \& Tamate, H. (1980). In Cell Proliferation in the Gastrointestinal

Tract [D. R. Appleton, J. P. Sunter and A. J. Watson, editors]. Tunbridge Wells: Pitman Medical Publishing. (In the Press.)

Sakata, T. \& Tamate, H. (1978a). Res. vet. Sci. 24, I.

Sakata, T. \& Tamate, H. (1978b). J. Dairy Sci. 6r, I Iog.

Sakata, T. \& Tamate, H. (1978c). Jap. J. zootech. Sci. 49, 687.

Sakata, T. \& Tamate, H. (1979). J. Dairy Sci. 62, 49.

Schnorr, B. \& Vollmerhaus, B. (1967). Zbl. Vet Med Ar4, 93.

Schnorr, B. \& Vollmerhaus, B. (I968). Zbl. Vet. Med. Ar5, 799. 
Snedecor, G. W. \& Cochran, W. G. (1967). Statistical Methods, 6th ed. Ames: The Iowa State University Press.

Stern, J. S., Baile, C. A. \& Mayer, J. (1970). Am. J. Physiol. 2rg, 84.

Szemerédy, G. \& Raul, R. (1976). Acta. Vet. Acad. Sci. Hung. 26, 313.

Tamate, H. (1957). Tohoku J. agric. Res. 8, 65.

Tamate, H. \& Kikuchi, T. (1978). Jap. J. vet. Sci. 40, 21.

Tamate, H., Kikuchi, T. \& Sakata, T. (1974). Tohoku J. agric. Res. 25, 142.

Tamate, H., Nagatani, T., Yoneya, S., Sakata, T. \& Miura, J. (1973). Tohoku J. agric. Res. $23,184$.

Trenkle, A. (1972). J. Dairy Sci. 55, 1200.

Weekes, T. E. C. (1972). J. agric. Sci., Camb. 79, 409.

Wright, J. A. (1973). Expl Cell Res. 78, 456. 